\title{
Community, Dialog and Technology - Maximizing Creating Shared Value (CSV) Nestle Indonesia
}

\author{
$1^{\mathrm{st} *}$ Arfika Pertiwi Putri \\ Communication Department \\ Dian Nuswantoro University \\ Semarang, Indonesia \\ Arfika.pertiwi.putri@gmail.com
}

Abstract - Creating Shared Value (CSV) is a concept of Nestlé's business strategy by seeking opportunities to connect its business programs from upstream to downstream (end to end), which was elaborated by Porter and Kramer (2006). Nestlé hopes to continue to be a long-term sustainable business that seeks to create mutual benefits not only with shareholders, shareholders but also the corporate community to the wider community. This research was conducted to find out the important elements of marketing communication in CSV. Qualitative research with this case study method approach bu grounded research uses the concept of marketing communication and cause-related marketing (CRM). The findings of this study are that CSV is a marketing communication program with cause and charity context. CSV focuses on interactive dialogues involving many elements of program recipients such as online and offline communities, learning-partners to achieve consumer-to-consumer dialogue (C2C) and from the community to consumers. The knowledge development dialogues between Nestle and all the elements form a 'learning together' with attention to the relevant contact points. Technological developments make CSV increasingly facilitate the company's relationship with consumers directly (B2C) and maximize the penetration of dialogue information to strengthen the values of CSV messages.

Keywords-CSV, Marketing communications, Nestle, Caused Related Marketing

\section{INTRODUCTION}

Nestlé is an organization with a joint venture, where Nestlé has the advantage that the organization can benefit from its local partners on knowledge about the conditions of competition, culture, language, political systems, and business systems in the country where the organization will be established, so Nestlé can develop quickly and build strong relationships. With the form of a joint venture, Nestlé successfully implemented the concept of shared value as a multinational program creating shared value (CSV). Creating shared value (CSV) is a business concept that creates profits or benefits for the organization and society in the long run. The concept of shared value lies in the progress of the economy and society following the principle of shared values. This value is defined not only as a material benefit of money but as a sustainable benefit. A value circle occurs; increasing value in an area will give each other opportunities and benefits. Shared value is a new way to better understand the environment, society, consumers, and productivity [1]. Porter and Kreamer define the concept of shared value as policies and ways of working practices to improve organizational competitiveness while simultaneously accelerating the economic and social conditions of the

\author{
$2^{\text {nd }}$ Agus Triyono \\ Communication Department \\ Dian Nuswantoro University \\ Semarang, Indoensia \\ agustriyono7@gmail.com
}

communities in which CSV is implemented [1]. Creating Shared Value (CSV) is a concept in business strategy that emphasizes the importance of including social problems and needs in the design of corporate strategies. CSV is a development of the concept of corporate social responsibility (CSR). One way for an organization to make a real commitment to their environment and to increase brand equity and sales so that it makes a difference with social elements is often called cause-related marketing (CRM) [2]. In 2018 Nestle has named the "Indonesia's Most Powerful Corporate Social Initiative 2018" for social initiatives considered the most powerful for beneficiaries and the sustainability of the company's business. The most prestigious award was only given to one winner, namely Nestle Indonesia [2]

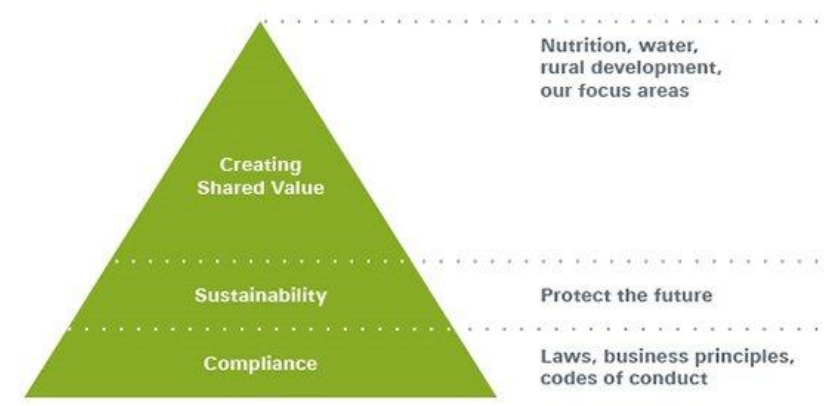

Fig. 1. CSV Nestle

source https://www.nestle.co.id/id/csv/menciptakanmanfaatbersama

There are certain values regarding the goals and needs of consumers. Nielsen's global data in June 2014 about consumers around the world showed $55 \%$ of consumers willing to buy more for products and services where the company is committed and has a positive impact on their environment and society [3]. Not only that, but there were also $52 \%$ of the world's consumers pay attention to the packaging of a product to ensure the effect of sustainability. And, there are $52 \%$ of consumers making a list since the previous six months to purchase products from companies that are socially responsible. Even $47 \%$ of consumers in the world are willing to donate their money and become volunteers to organizations that do good to the environment and society. Fundamentally communication becomes very essential for individuals, relationships, groups, organizations as well as for society. Communication is about responding and making messages and there are various functions of communication such as social needs as a means of interaction with others, the need for inclusion to interact with others so that messages can be conveyed properly. In later 
practice, corporate values can be communicated in a variety of ways and channels. Seeing from the previous presentation, the formulation of the problem from this research is how to maximize the communication element in creating Nestle Indonesia's program of shared value (CSV)?

\section{RESEARCH METHOD}

This research is a qualitative exploratory research type using a grounded research approach and case study research methods. Descriptive data presupposes that the data is in the form of text, there is a detailed presentation of data which means creating a 'feeling of being there'. This research also emphasizes the process, means seeing facts, realities, symptoms, and events that occur and are experienced and participant perceptions are the main keys. Another characteristic that is looking for a deep understanding (verstehen). This method wants to learn how people understand something. Denzin and Lincoln suggest that qualitative research is aimed at achieving a deeper understanding of specific organizations or events rather than describing the surface portion of a large sample of a population [2]. According to Banister qualitative research is a method for capturing and giving a picture of a phenomenon, and as a method for explaining a phenomenon under study. Grounded research is a model approach in qualitative research that is conceptual or theoretical as a result of inductive thinking from data generated in the research of a phenomenon or a theory that is built from data of a phenomenon and is analyzed inductively, not the result of the development of existing theories [2]. Researchers use grounded research because this method is suitable for finding or producing conceptual communication activities in creating shared value of PT. Nestlé Indonesia with consumers. Strauss and Corbin explain that theories consist of various 'plausible' relationships that occur between 'concepts' and 'concepts' [3]. The concept used is the concept of marketing communication and caused related marketing (CRM). The researcher collected primary and secondary data by conducting interviews with Nestle corporate communication and secondary data on the CSV annual report.ding 2)

\section{RESULT AND DISCUSSION}

\section{A. Cause and Charity Context}

CSV with Cause and Charity Context The CSV idea emphasizes the opportunity to build a competitive advantage by including social issues as the main consideration in designing corporate strategies in this case including the communication strategy. All the communicated activities that are collected as Creating Shared Value (CSV) or create shared benefits have an element of Cause or Charity. Values represented as a shared benefit need to emphasize what aspects can be done by companies with the social needs of consumers. Cause and Charity can be in the form of the environment, the wider community, and consumers themselves. Cause and charity in the environment, for example, is with Nescafe Plan Nescafe cares about the rejuvenation of coffee that is now old. In its report in the same year Nestle, more focused its focus on the environment, the last is the STOPS program that concentrates on the use of plastic waste where this report can be accessed by anyone different from previous years which many provide reports with consumers. In the community, for example, in the borehole supply program which includes the entire community. Charity and cause with consumers, for example, with various campaigns that Nestle undertakes, such as "Berbagi Pesan".

Context is a basic reference that frames intentions and actions. Commercial activities between business and charity or other causes that can take the form of cooperation with one another for the image of the market, products or services are mutually beneficial is called cause related marketing (CRM) [4]. In CSV aspects of cause and charity are a prominent part in every activity. The initiative to provide 18 million coffee seeds is an element of charity and cause which is then included in the make up for the packaging that is notified to the wider community. Two large sectors that have been seriously worked on for CSV between Nestle and the corporate community are coffee and milk. Because of that the two packaging variants, Dancow and Nescafe have included beyond the label or beyond the cup.

The benefits that can be obtained by an organization with the cause-related marketing (CRM) activities are related to marketing, increasing product sales, and including attracting new potential customers, reaching niche markets, and building brand positions. With the beyond the label, beyond the cup as well as various other activities in the Nescafe Plan, will give awareness to new potential consumers, for example, other young people who have not consumed Nescafe but are exposed to the program. Thus the position of the Nescafe brand is not just an ordinary coffee mix, but there is a new value formed there and its position as a brand that cares about the welfare of farmers creates new empathy for consumers. Policies and activities that are effectively communicated between the company's internal and external companies to enhance the company's reputation; reflecting company values, building positive perceptions, loyalty among stakeholder groups and potentially increasing consumer sales flow.

The Nescafe Plan, for example, is truly communicated to consumers, seen in the activities carried out by the finalists \#DiBalikSecangkirKopi \#IniBaruHife where all the finalists are told that the activities Nescafe does are to prosper the coffee farmers in Tanggamus. Proven to bring all finalist to the place of a successful coffee farmer who was once a motorcycle. In the "Berbagi Pesan" activity that was formerly "Sarapan Sehat" by involving consumers as the direct experience which has now turned into a charity where if the consumer submits a message, it means that the consumer has given breakfast to other Indonesian children who need breakfast. This activity is a form of making a wider target audience and giving new awareness to more people if once only one or two cities now all who access the internet can do the activity. There is a relationship between marketing mix with cause-related marketing by immersing company values and following the objectives of the program so that there is formation in the market that is the image of the product or service. The integration of these two things is like two sides of a pair of scissors, then the one that cuts consumer trust paper, product image, to loyalty is not just the marketing mix of communication, but the result of clipping both sides of the scissors namely caused related marketing and communication mix marketing. 


\section{B. Program Structure Of CSV}

Creating shared value (CSV) as a business strategy concept is then reduced to various programs. The program in CSV is a combination of company values combined with values by Porter and Kramer in the CSV concept that is shared benefits or as global values. Existing programs can start from existing social problems (problem solvers), new Nestle initiatives or innovations in programs that have been running in the community. Problems that are seen may originate from social problems that exist in the community which is carried out with research first, but some are connected with Nestle's raw materials. Furthermore, the program will be formulated according to and needed and adapted to the existing business units. Also, Nestle will find the right partner for the program.

One of the programs is Nutrisi Seimbang Menuju Sehat, initiated after Nestle researched the magnitude of the role of PUSKESMAS as a source of information for the community, especially mothers. Nestle created a program for refreshment on basic nutrition, balanced food and healthy lifestyles in collaboration with the Department of Health and the Indonesian Medical Doctors Association. The problem with Nestle's raw material, for example, is the Nescafe Plan. In this program Nescafe invites everyone to be more concerned with Indonesian coffee where Nescfae has donated 18 million million seedlings Nescafe in Lampung Province as the biggest Robusta coffee producer in Indonesia.

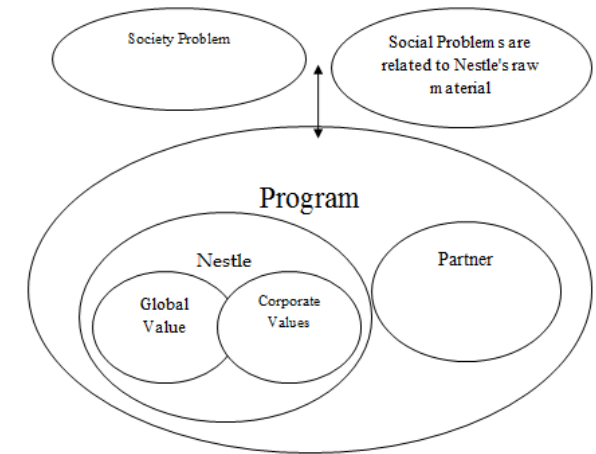

Fig. 2. Program Stucture CSV Nestle Indonesia. Source: Processed researchers

\section{Offline and Online Programs with Target Audience}

Offline and online programs are carried out by Nestlé in CSV with consumers and the community aimed at educating nutrition to consumers and the public. In the implementation there is also the role of opinion leader and opinion former. In the StimuLearn launch program for example Dancow invited Indra Bekti and his family, then in the \#DiBalikSecangkirKopi \#IniBaruHidup program using the @fiksimini@Amrazing@OdieFrente account buzzer.

\section{a) Program Offline}

Offline Program The program to educate nutrition to consumers targeting mothers is mostly carried out by Nestlé. Among them such as Nestlé Breakfast Cereal Arisan which aims to share knowledge about the importance of breakfast, good breakfast types and nutritional content in various types of breakfast. Nestlé breakfast gathering in 2011 was held from October to December 2012 was held from February to July, where the venue was a housing complex and targeted women. There is also the Nestlé Wellness Challenge Friends program which is a 90-day program, participants who are families take part in various activities including workshops, running a healthy lifestyle, and regular exercise training at a fitness center in Jakarta that is Nestlé's partner. Furthermore, the "Nestlé Healthy Country" program, which targets almost all stakeholders and the public, displays 16 exhibition stands showing various Nestlé products for various walks of life, also exhibiting various programs in an effort to meet halal requirements and programs that create mutual benefits, summarized in Creating Shared Value (CSV). The offline program that Nestlé had just completed in early 2015 was \#DiBalikSecangkirKopi which invited ten winners of the \#IniBaruHidup story competition to the factory in Tanggamus Lampung. There was a direct interaction between consumers and the community of companies related to coffee. All finalists also paid a company visit to the Nescafe factory.

\section{b) Online Program}

A growing era allows interactive interaction. This was later used by Nestlé in CSV. Nestlé has an abundance of social media assets such as Twitter Dancow Parenting Center @DancowCentre, Facebook Nescafe, Facebook Koko Crunch, Nestlé's Friends Youtube Channel, SahabatNestlé's website, to their new program StimuLearn application, and the program www.berbagipesan.co.id. This online interaction also creates new interactions between consumers and consumers where one consumer eventually spreads to other consumers

In 2008 in the Friends of Nestlé Wellness Challenge program participants who had participated in a program where their conditions were monitored by a team of experts from the fitness center, and through the Friends of Nestlé website the participants also wrote their progress in following the program on a blog. This is done in addition to further increase interaction between members of Nestlé Friends, it is also expected to inspire other members to adopt a healthy lifestyle.

In 2013 the Nescafe Plan launched a campaign on social media with the aim of the public being increasingly concerned with the condition of coffee in Indonesia in the form of viral videos distributed via Facebook. In 2014 the Nescafe Plan with the story \#IniBaruHidup \#DiBalikSecangkirKopi with a blog contest and the winners visited the company then rewritten and distributed through the participant's social media accounts and Nescafe. Then there was also a change in the campaign for healthy breakfast, which was originally offline to take the form of an online message sharing program. Berbagi Pesan was delivered by campaig the importance of Nestlé's healthy breakfast which invites all Indonesian people to share healthy breakfast with Indonesian children by participating in Berbagi Pesan campaign. Some messages found at www.berbagipesan.co.id: 


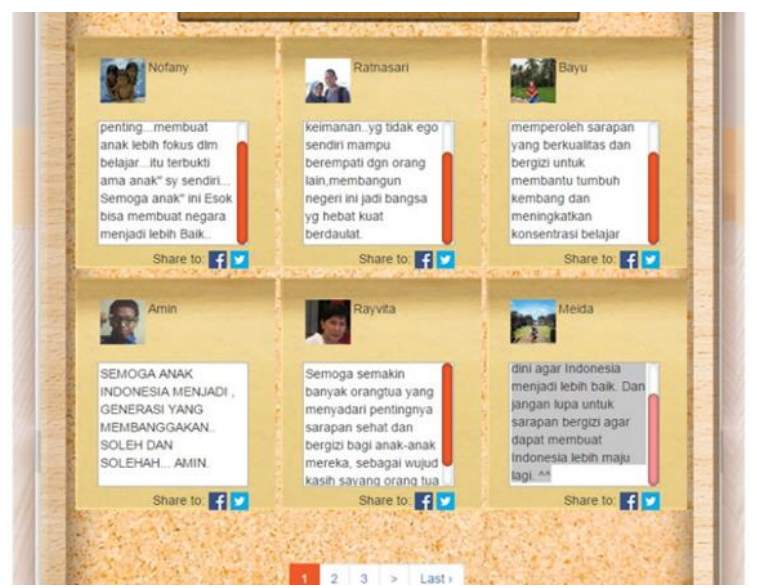

Fig. 3. 'BerbagiPesan' source: www.berbagipesan.co.id

\section{Offering 'Innovation' to Target Audience}

Nestlé in its CSV programs presents innovation as an idea or object that is considered new by the target audience. Dancow Caravan Nutrition develops a "Little Doctor" program with nutrition education being a "Little Doctor Advanced Nutritionist" The addition of this new value with the addition of educational innovation compatibility about nutrition, health and personal hygiene for elementary school students, teachers and parents. The Dancow Parenting Center which presents the StimuLearn program is designed to help parents stimulate children's learning and exploration processes online (through applications) and offline (real interactive programs) is a relative advantage of innovation offered by Dancow to its target audience. The Nestlé Healthy Kids (NHK) program reinvigorates the School Health Unit (UKS) of primary schools and makes education modules for students, as well as providing health training and seminars to teachers and school stakeholders is a form of adding new values to the target audience. In the Nestlé innovation village development program one of them is on the posyandu movement with revitalization to become a posyandu caring for TAT (Growing-Active-Responsive). One of the liability innovations carried out is the launch of a guidebook for cadres of Posyandu "toolkits". This module is a complete guide for Posyandu cadres to motivate and empower parents in implementing growth-active-responsive parenting.

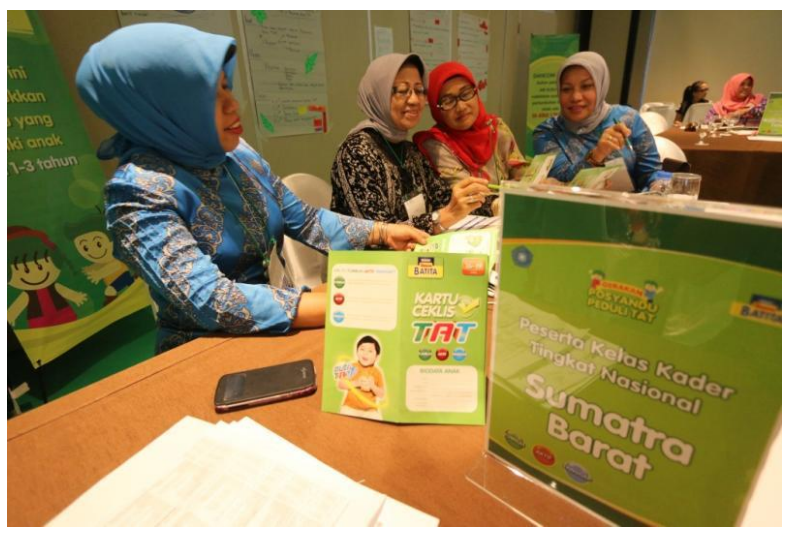

Fig. 4. Toolkit pada Posyandu TAT source http://m.liputan6.com/health/read/2099205/posyandu-kini-mulai-diminatilagi

\section{E. Collaboration in Nestlé Indonesia CSV}

In CSV, Nestlé collaborates and collaborates with various parties to optimize the performance of each program. The collaboration and collaboration among others are with the consumer community, sales partners, and related stakeholders and organizations. The findings show that collaboration with this community will be based on shared values, goals, vision and mission. This collaboration and collaboration will be realized in the form of various programs.

\section{1) community}

In the CSV program, Nestle works with the community to be able to reach wider consumers. Communities in CSV interact with programs according to their respective contexts. These communities include the bloggers who collaborate with the Dancow Parenting Center on the Dancow StimuLearn program. There is an interaction between Dancow and parents of community members to trial the application and spread the StimuLearn application in which there is a bloggers competition to introduce the StimuLearn application to wider consumers. Other communities such as the writer's community @fiksimini with Nescafe in the \#DiBalikSecangkirKopi Nescafe Plan program. This collaboration also deals with a competition organized by Nescafe with a prize trip to Tanggamus, Lampung, the Nescafe factory. Furthermore, collaboration with Posyandu with Dancow Batita and Datita aimed at increasing the knowledge of posyandu cadres and inviting more and more people to come to Posyandu.

\section{2) Sales Partners}

CSV presents cooperation with sales partners to support its events. Most of them are as a place to do programs, as well as collaboration in the form of programs because many markets also meet there. Recorded in the 2013 CSV report, there are five cooperation partners between Nestlé and its selling partners, namely: Lotte, Hypermart, Carrefour, Dairy Farm, Lion Superindo and Yogya. This collaboration with events such as Nestlé Health and Nutrition Fair which provides nutritional consultations to consumers, at the Milo and Koko Krunch 2014 "National Breakfast Week" campaign, Nestlé collaborates with Carrefour. Koko Krunch in collaboration with Chandra Superstore in December 2014 held a drawing and coloring contest at the elementary school level where the event was to invite all parents to understand and care about the importance of good and nutritious food for children.Nestlé MILO chocolate powder drink, in collaboration with LOTTE Mart, in June 2014 gave soccer scholarships to 20 gifted but underprivileged children aged 8-12 years. The MILO-LOTTE Mart football scholarship awarded through the Asian Soccer Academy (ASA) includes soccer training and education, as well as knowledge about health and nutrition for a year. The MILO-LOTTE Mart Football Scholarship Program is part of the Nestlé MILO campaign "Giving a Thousand Birth Birth Tens of Champions" conducted at LOTTE Mart outlets from March to June 2014.

\section{3) Stakeholders and Related Organizations}

Nestlé's collaboration with stakeholders includes government and related institutions. Collaboration with stakeholders and related organizations will be by the focus of 
CSV. Realize collaboration with stakeholders in the focus of water, village development or nutrition. The forms of cooperation are also varied, some are in the form of sponsorships, investor cooperation or also learning partners. In the MILO Jakarta International $10 \mathrm{~K}$ which was held to welcome the 487th anniversary of DKI Jakarta, Nestlé's role in the program was the main sponsor. In other CSV programs such as village development in partnership with Nestle Cocoa farmers, they also work closely with the government of West Sulawesi. Nestlé also joined as a member of the Indonesia Global Compact Network (IGCN) in the "Save Water" campaign.

\section{F. Dialogue, Interaction, and Innovation in Nestle Indonesia's CSV}

Nestle's concentration is to educate. The essence of CSV is education to consumers, the community and the wider community. Dialogue that occurs is a form of mutual education about nutrition and products. Dialogue that occurs is starting from dialogue mutuality, propinquity, empathy, the risk to commitment. Empathy dialogue for example in the Nescafe Plan \#DiBalikSecangkirKopi \#InBaruHife life program in which Nestle invites consumers who in this case are represented by selected finalists (bloggers, travelers, coffee lovers) to come to Tanggamus and interact with coffee farmers, Nescafe workers to do various activities in Nescafe factory. In the Nescafe Plan \#DiBalikSecangkirKopi program, finalists were also asked to spread their stories with various existing social media assets. This dialogue occurs between consumers and consumers, consumers and companies for example through products or other channels. Other interactions, for example, in the Nestlé Wellness Challenge program, include 100 interested families in Jakarta and 20 selected families to participate.In this program, consumers have a direct dialogue with Nestle, a fellow consumer. Nestlé aims to become a leading company in nutrition, health, and wellness (nutrition, health, and wellness) direct interaction on the nutrition education side. Nutrition education for consumers becomes the core of CSV with consumers. Besides, there is also education indirectly to consumers with the relationship between the focus of village development and water. This education is in the form of knowledge about the Nestlé program that creates mutual benefits for water and village development. Whereby following the contents of the event, consumers can find out about the story behind the production of Nescafe products originating from domestic coffees, by Indonesian farmers who are well developed by Nestle, given the best seeds from Nestle's collaboration with the Coffee and Cocoa Research Center (Indonesian Coffee and Cocoa Research). In other words, there is consumer education about the product (product knowledge).

Dialogue with the development and knowledge that has involvement makes there is a "Learning Together" between companies, consumers, the consumer community, the corporate community, and related partners. There is two-way communication that is done formally and informally by listening and learning. This is manifested in almost all programs involving consumers. In the Healthy Breakfast Arisan program, for example, consumers (mothers) receive education about healthy breakfast choices from Nestle in their community, namely social gathering. In the \#DIBalikSecangkirKopi program, for example, Nescafe conducts education by freeing finalists to ask questions directly with the company community, meaning there is awareness about things Nestle does in its Nescafe products, education is carried out virally as well as carried out with a campaign on Facebook where Nestle (Nescafe) invites The community participates through Facebook Nescafe in its coffee rejuvenation efforts, in this video Nicholas Saputra (brand ambassador) invites all coffee buddies to support the coffee rejuvenation movement by watching the video, liking, and spreading it to everyone. There is also the Dancow Parenting Center program which has a website that makes this an offline community where members can share as much as at www.sahabatnestle.co.id. In the StimuLearn Dancow Parenting Center blogger contest, consumers are also asked to write a review about StimuLearn Apps on a personal blog, along with photos or videos with children while playing StimuLearn Apps and then participants are asked to upload a blog post link to the Blogger Emak2 Collection blog. That is, there is education on the use of apps one consumer with other consumers. Other education conducted by Nestle, for example, Nestlé in collaboration with the Emmanuel Foundation, a non-governmental organization specializing in the education of elementary school children in Bogor, West Java, provides education about healthy living and nutrition, with the hope that they can disseminate it at home and in the surrounding environment, and continuing healthy living habits.

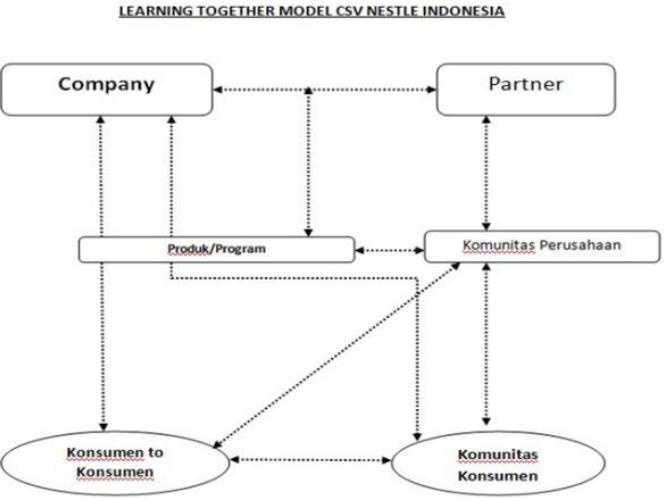

Fig. 5. "Learning Together" Dialog CSV Nestle Indonesia by Researcher

This interaction shows a lot of involvement between consumers and Nestle to allow for involvement, high involvement, and low involvement. Researchers found similarities in each CSV program, including:

- Individual context: values, expectations, and experience

- Nature with products: direct and indirect

- Nature stimulus: consumers, media and experts

- Focus: products and communication

- Personal relevance: high

- Response view: cognitive processes and behavior (learn, feel, do)

In implementing CSV programs, there are several forms of interaction that occur between consumers and the community. This interaction is carried out in a certain amount of time and is ongoing. This interaction is also motivated by Nestlé's efforts to reach a wider target audience. Besides, Nestlé also uses certain moments to 
interact. In this dialogue, interaction and involvement of the consumer (target audience) will get exposure to the innovations carried out by Nestle in its programs.

\section{CONCLUSION}

The value penetration dialogue is a key element of Nestlé's CSV communication activities with consumers. The penetration of these values was reduced to various programs that were in line with Nestlé's CSV focus namely, water, village development, and nutrition. Furthermore, the three focuses are integrated to be communicated to consumers. The program created is a translation of shared values between consumers and companies that has a message that is communicated. In practice, many programs intersect Nestlé's marketing communication with its consumers. However, in CSV these programs must have an element of global value, or as mentioned by Michel Porter in their concept of CSV that there are shared values that benefit the community. A global value that occurs between consumers and companies is connected by communication activities. This activity involves many roles ranging from consumers, learning partners, media, opinion leaders, opinion former, community, virtual communities with various factors. Then this activity allows for more interactive interactions. because of technological advances that connect one role to another.

\section{REFERENCES}

[1] M. E. Porter and M. R. Kramer, "The Big Idea : Creating Shared Value," Harvard Business Riview , pp. 1-12, 2011.

[2] Nestle, "Creating Shared Value Report," Nestle Indonesia , Jakarta , 2013.

[3] Nielsen, "Global Data Report," Nielsen , US, 2014.

[4] H. Herdiansyah, Metodologi Penelitian Qualitatif, Jakarta : Salemba Humanika, 2011.

[5] N. K. Denzin and Y. S. Lincoln, The SAGE Handbook of Qualitative Research, US: Sage Publications, 2017.

[6] S. Adkins, Cause Related Marketing Who Cares Wins, Oxford : Butterworth Heinemann, 1999. 